\title{
Становление и развитие кинофикации в Тувинской Народной Республике
}

\author{
Белекмаа В. Мунге \\ Национальный архив Республики Тыва, Российская Федерация, \\ Арана М. Монгуш
}

Хакасский государственный университет им. Н. Ф. Катанова; Тувинский научный центр, Российская Федерация
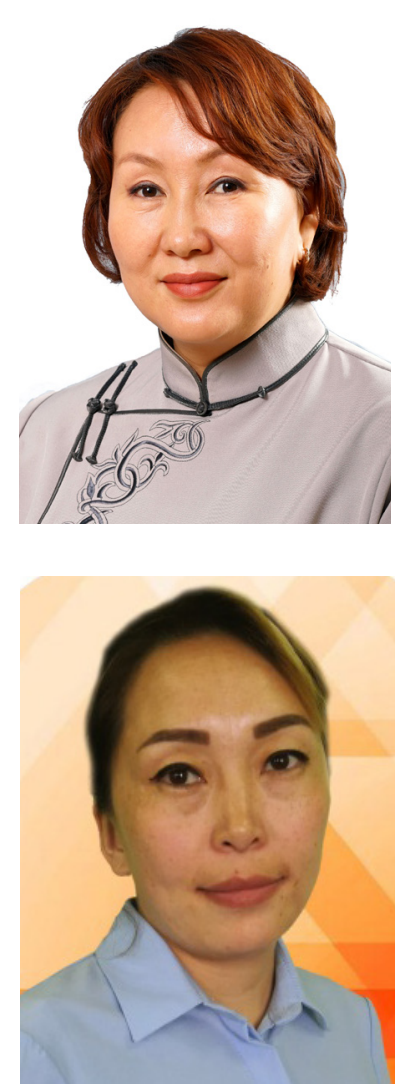

В статье анализируется история кинофикации в Тувинской Народной Республике, в том числе во время Великой Отечественной войны. Источниковой базой исследования стали изданные труды, архивные документы периода ТНР, в том числе впервые вводимые в научный оборот; привлекаются воспоминания очевидиев событий.

Первая стационарная киноустановка в Туве появилась в 1925 г. в клубе советских граждан. Она показывала документальные фильмы, переданные от СССР. В 1930 г. был создан Тувгоскино, составлен план кинофикации, решались всевозможные организационные проблемы: оснащенность, бюджет, перебои снабжения, качество кинокартин, переводы на тувинский язык. В 1931 г. в г. Кызыле был открыт первый кинотеатр, стали функционировать две передвижные установки. В середине 1930-х г2. развертывается сеть киноустановок, усиливается материально-техническая база. В 1936 г. на празднование XV годовщины ТНР делегация СССР привезла новые аппараты в дар, а тажже советские операторы сняли ряд фильмов о Туве. Количество передвижных киноустановок с 1932 по 1937 г2. увеличилось в 2 раза. С расширением кинофикации в республике назревает острая проблема обеспечения кадрами.

В годы Великой Отечественной войны отрасль кино также решала задачи военного времени. Изменения коснулись всей системы киносети, репертуарной политики и кинопроката республики. Репертуарная политика военного периода стала важным средством в патриотическом воспитании общества. Киносеть Тувы продолжила свое развитие уже в составе СССР, вливщись в единую систему советского кинопроката.

Ключевые слова: культурное строительство; киноустановка; кинотеатр; кинорепертуар; кинофикация; история кино; Тува; история Тувы; Тувинская Народная Республика; тувинцы; Великая Отечественная война

\section{Для цитирования:}

Мунге Б. В., Монгуш А. М. Становление и развитие кинофикации в Тувинской Народной Республике // Новые исследования Тувы. 2020, № 3. С. 81-100. DOI: www.doi.org/10.25178/nit.2020.3.6

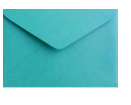

Мунге Белекмаа Владимировна - директор Национального архива Республики Тыва. Адрес: 667010, Россия, г. Кызыл, ул. Кечил-оола, д. 91. Тел.: +7 (394-22) 5-63-15. Эл. адрес: mungeb@me.com

Монгуш Арана Михайловна - магистрант кафедры истории России Хакасского государственного университета им. Н. Ф. Катанова; методист отдела научного сопровождения регионального образования Тувинского научного центра. Адрес: 667003, Россия, г. Кызыл, ул. Вокзальная, д. 13. Тел.: +7 (962) 064-40-65. Эл. адрес: oyun.arana@mail.ru

MUNGE, Belekmaa Vladimirovna, Director of the National Archives of the Republic of Tuva. Postal address: 91 Kechil-oola Str., Kyzyl, Russian Federation 667010. Tel. +7 (394-22) 5-63-15. E-mail: mungeb@me.com ORCID ID: 0000-0002-4432-4395

MONGUSH, Arana Mihaylovna, master's student OF the Khakass state University named after N. F. Katanov, methodist of the Department of scientific support of regional education of the Tuva research center. Postal address: 13 Vokzalnaya str., Kyzyl, Russian Federation 667003. Tel.: +7 (962) 064-4065.E-mail: oyun.arana@mail.ru ORCID ID: 0000-0002-3950-069X 


\title{
Formation and development of the cinema network in the Tuvan People's Republic
}

\author{
Belekmaa V. Munge \\ National Archives of the Republic of Tuva, Russian Federation \\ Arana M. Mongush \\ N. F. Katanov Khakassia State University, Tuvan Research Center, Russian Federation
}

This article examines the history of the cinema network in the Tuvan People's Republic, including the years of the Great Patriotic War. The article is based on the analysis of printed materials and archival sources, with some of the latter never been studied before. Another important source are eyewitnesses' memories.

The earliest stationary cinema installation appeared in Tuva in 1925, at the Soviet citizens' club. The documentaries run there were supplied by the USSR. In 1930, TuvGosKino (Tuvan Cinematographic Office) was set up, the plan of cinema development was drawn up, and a number of organizational issues resolved, such as the Office's equipment, budget, supply lines, film quality and Tuvan translation. The first cinema was opened in Kyzyl in 1931, and two mobile installations went operational the same year. A whole network of installations had been in place by mid-1930s, with material basis a lot improved. At the celebration of TPR's 15th anniversary in 1936, the Soviet delegation presented new equipment. Soviet camera crews made a number of films on Tuva. Between 1932 and 1937, the number of mobile cinema installations in Tuva increased twofold. With the spread of cinema across the republic, the problem of cadres got increasingly urgent.

During the war years, cinema had to deal with war-related issues. The whole cinema network experienced a drastic change, just as it happened to the repertoire selection and film distribution. The wartime repertoire was a crucial factor in the patriotic education. After the war, Tuva's cinema network joined its larger counterpart of the USSR and continued as part of the single Soviet film distribution system.

Keywords: culture-building; film installations; cinema; film repertoire; movie circuit; history of the cinema; Tuva; history of Tuva; Tuvan People’s Republic; Tuvans; Great Patriotic war

Munge B. V. and Mongush A. M. Stanovlenie i razvitie kinofikatsii v Tuvinskoi Narodnoi Respublike [Formation and development of the cinema network in the Tuvan People's Republic]. New Research of Tuva, 2020, no. 3, pp. 81-100. (In Russ.). DOI: www.doi.org/10.25178/nit.2020.3.6

\section{Введение}

Программа социокультурных преобразований, т. н. культурная революция, начатая в 1930 г. в Тувинской Народной Республике (ТНР) предполагала активную борьбу с неграмотностью населения, организацию системы образования и просвещения, создание нового облика и морали трудящегося населения с использованием новых методов пропаганды и агитации. Кино также было отведено особое место в этом деле.

История культурной политики периода ТНР анализировалась во многих работах, начиная с «Истории Тувы» (История Тувы, 2007: 243-314), а также: Л. П. Потапова (Потапов, 1953), Н. А. Сердобова (Сердобов, 1971), С.К. Тока (Тока, 1970), М.Х. Маннай-оола (Маннай-оол, 2001), но проблема становления системы кинофикации в данных работах не раскрывается. В то же время в исследованиях по истории культуры Тувы встречаются отдельные данные по становлению киносети, первых кинопередвижках. В книге О. Менхен-Хельфена (Менхен-Хельфен, 2007), в монографиях Ю. Л. Аранчына (Аранчын, 1982), А. К. Кужугет (Кужугет, 2006), в шестом томе антологии «Урянхай. Тыва дептер» (Введение, 2007: 106), в книге «Кызыл - столица Советской Тувы» (Кызыл - столица ..., 1964), в статьях Н. М. Моллерова (Моллеров, 1988) - приводятся сведения о появлении первых кинопередвижек в ТНР, демонстрации первых фильмов. Отдельные аспекты темы поднимались также одним из соавторов данной статьи в предыдущей работе (Бадыргы, Мунге, 2020).

Целью данной работы является анализ истории кинофикации в ТНР, в том числе во время Великой Отечественной войны. Кинофикацию мы рассматриваем как «систему мероприятий, обеспечивающих 
развитие киносети и кинообслуживание населения» (Кино: ..., 1986: 197). Сюда входит вся система киносети и кинообслуживания населения, с организованной структурой управления киносети, включающий в себя создание материально-технической базы, обеспечение кадрами, контроль в области репертуарной политики и работу со зрителем. Киносеть включает в себя «совокупность культурнозрелищных предприятий, осуществляющих показ фильмов населению, - кинотеатры, клубы и др.» (Киносеть, 1973: 138).

Источниковой базой исследования стали изданные труды по истории ТНР, архивные документы периода ТНР, содержащие нормативно-правовые документы законодательной и исполнительной органов власти, переписка Министерства иностранных дел ТНР с организациями и учреждениями в СССР, газетная периодика. Все эти документы хранятся в Национальном архиве Республики Тыва (НА РТ). При этом в работе впервые в научный оборот вводятся материалы фонда 145 «Управление Тувинского государственного кино при Совете Министров ТНР» (НА РТ, ф. 145, 3 ед. хр., 1940-1944 гг.), а также документы по становлению киносети из фонда «Центрального Комитета тувинской народнореволюционной партии» (НА РТ, фп-1, 3349 ед. хр., 1882-1944 гг.). Также привлекаются воспоминания очевидцев событий, опубликованные в газетах и полученные в ходе интервью авторов в 2020 г.

\section{Становление киносети в Тувинской Народной Республике}

Образование государственности в 1921 г. положило начало развитию народного хозяйства и культуры, социальным преобразованиям в ТНР. В условиях отсутствия в Туве в начале XX в. национальной письменности, начальных школ, культурных и медицинских учреждений, большую помощь в становлении всех этих отраслей, которые в целом назывались культурным строительством, молодой республике Танну-Тува оказывал Советский Союз.

При этом, если сравнивать развитие киносети ТНР с советскими регионами Сибири, то можно сказать, что в Туву кино пришло гораздо позже. Так, первые кинопередвижки в Томске появились в 1898 г. (Косых, Фадеев, 2005), в Бурятии - в 1924 г. (Бураева, Батурин, 2017), в Горном Алтае также - в 1924 г. (История Горного ..., 2014), в Хакасии в 1920-х гг. (Энциклопедия Республики ..., 2007: 275).

В архивном фонде «Совета Министров ТНР» НА РТ хранится документ под заголовком «Вопросы делегации СССР» от 1930 г., где зафиксированы основные виды помощи со стороны СССР, которые были сформулированы и подписаны министром культуры Тока и заведующим Тувздрава Руденко. Так, в разделе V. Помощь по кинофикации республике обозначено: «Значение киноработы общеизвестно. Конкретно помощь со стороны СССР может быть осуществлена: 1. Льготное снабжение кинопрокатом. 2. Льготное снабжение киноаппаратурой. 3. Посылка экспедиции для киносъемок. 4. Непосредственное участие киноорганизаций СССР в развертывании киноработы в Республике» (НА РТ, ф. 92, оп. 1, д. 54, л. 32-33).

В «Истории Тувы» указывается, что первая стационарная киноустановка в Туве появилась в 1925 г. в клубе советских граждан. Аппаратура была передана полномочным представительством СССР в безвозмездное пользование правительству ТНР (История Тувы, 2007: 305). Новость об этом событии тут же вышла в местных газетах, в частности «Красный пахарь» от 21 января 1926 г. № 3 (57), текст которой был впоследствии перепечатан уже в 1982 г.: «в городе Красном начал работать кинематограф... В дальнейшем, кинопередвижка будет регулярно посещать все поселки» ${ }^{1}$ В другом номере этой же газеты (от 6 февраля 1926 г. № 5) писалось, что показ первого кино для тувинцев стал историческим событием. Этот текст также был перепечатан позже в 1971 г.

Показ «привлек к себе сильный интерес тувинцев. Ведь до настоящего времени они о нем и понятия не имели... На днях прибыли из далекого Хемчикского хошуна представители партийных организаций. Посетили кино, и оно произвело на них неизгладимое впечатление. Целую ночь после этого они просидели и проговорили о том, какие чудеса творит наука, и как далеко они, тувинцы, еще отстали в своем культурном развитии» ${ }^{2}$.

Данная кинопередвижка, установленная в клубе советских граждан, как пишет Н. М. Моллеров, прибывает в г. Чадан и показывает аратам документальные фильмы (Моллеров, 1988: 103). В 1928 г. полномочное представительство СССР передает эту киноустановку правительству ТНР (Аранчын, 1982: 232).

${ }^{1}$ Сантьева Т. Живые картины // Тувинская правда (газета). 1982. 27 августа. С. 4.

${ }^{2}$ Титенков А. Первое кино в Туве // Тувинская правда (газета). 1971. 4 апреля. С. 4. 
Австрийский исследователь О. Менхен-Хельфен в 1929 г. посетил Туву в составе экспедиции Коммунистического университета трудящихся Востока (КУТВ) и по итогам написал книгу «Путешествие в азиатскую Туву» (Менхен-Хельфен, 2007). Здесь он описал свой поход в кино и реакцию зрителей:

«Электростанция работает допоздна только в “киношные” дни. Я смотрел там замечательный фильм “Мать” по книге Горького. Кино крутят не каждый день, максимум - два раза в неделю, а иногда ждать очередного киносеанса приходится довольно долго. Чтобы взглянуть на это чудо тувинцы приезжают издалека. Двадцать, тридцать километров - разве для этих всадников расстояние имеет значение?!

Они сидели на узких деревянных скамейках, в жуткой тесноте и напряженном ожидании. Моим соседом оказался шаман, которому накануне пришлось отправить свою душу в царство к Эрлик-орану - в страну мёртвых... а теперь он сидит в кино, рядом с ним солдат, чуть подальше монгольский посланник, затем лама, дети, старые женщины, юные девушки, мужчины, перебирающие в руках четки со 108 жемчужинами.

В этот вечер пленка обрывалась, по крайней мере, раз двадцать. Но это только прибавляло зрителям радости. Тем лучше! Тем дольше продлится сказка!.. Титры были на русском, но они не могли их прочесть, тем не менее, радость их была бесконечной. Как только показались лошади, весь зал пришел в полный восторг. Они соскочили с мест, закричали, подгоняя лошадей дикими возгласами: “Че! Че!”. Кино доставляло всем истинное удовольствие...» (там же: 249-250) (фото 1).

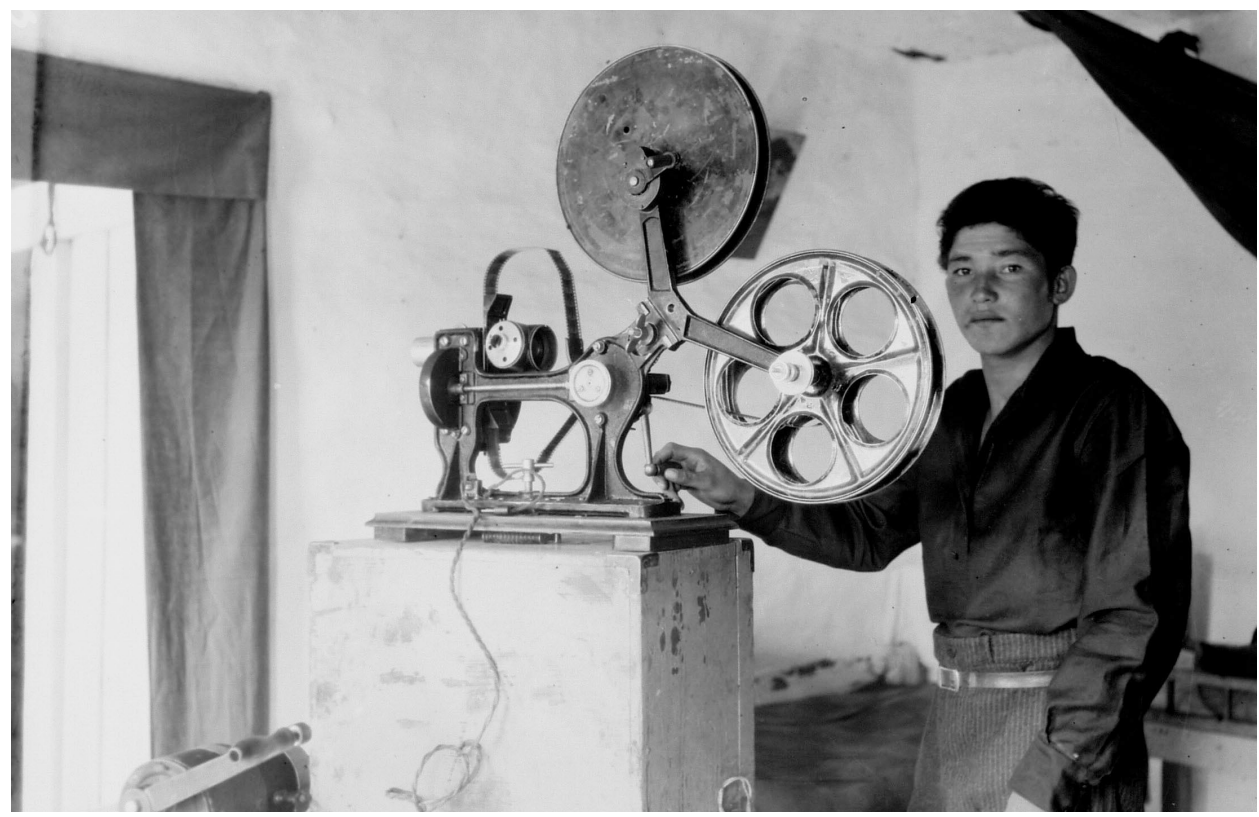

Фото 1. Одна из первых киноустановок в Кызыле, 1926 г. (НМ РТ, КП-11286-233).

Photo 1. One of the first cinema installations in Kyzyl, 1926. (NM RT, KP-11286-233).

В архивных документах упоминание о кинопередвижках имеется в докладе С. К. Тока в «Тезисах о задачах культурного строительства в Туве» 1930 г., что «Министерство по культурным делам предприняло некоторые меры: организованы 3 юрты-передвижки и 1 кинопередвижка в г. Кызыле» (НА РТ, ф. 92, оп. 1, д. 54, л. 20).

Руководство республики, понимая важное место кино в пропаганде и агитации нового общественного строя и учитывая большой интерес населения к проекционному искусству, принимает меры по созданию руководящего органа и дальнейшего развития киносети.

В фонде НА РТ, фп-1 «Центральный Комитет Тувинской Народно-Революционной партии (ЦК ТНРП)», оП. 1, д. 950 «Постановления политбюро и АПО ЦК ТНРП о госбюджете ТНР и создании Тувгоскино (проекты)...» хранится доклад механика кинопередвижки г. Кызыла, товарища Бердова. В нем описывается общее состояние имеющихся кинопередвижек в ТНР (были также закуплены еще две русским населением в Подхребтинском и Туранском хошунах, за счет самообложения), предложение о создании руководящего органа кинофикации, отвечающего за развитие киносети, материальнотехнического состояния передвижек, регулярное снабжение фильмами. 
Из доклада Бердова видно, что передвижная установка г. Кызыла в экспериментальном плане выезжала в близлежащие населенные пункты с целью определения расходов и посещаемости кино. Для полноценного охвата территорий кинообслуживанием он предлагает закупить кинопередвижки в следующие хошунные центры:

1. Самагалтай и Подхребтинский хошуун,

2. Харал-Малоенисейский хошун,

3. Туранский хошун,

4. Шагонарский хошун-Эйлихем,

5. Чадан.

Далее механик кинопередвижки Бердов указывает на необходимость установления связей с Совкино для закупа запасных частей и приобретения фильмов на прокат (НА РТ, ф. 1, оп.1, д. 950, л. 5).

Очевидно, вышеуказанный доклад стал основой для проведения заседания коллегии АПО ЦК АРП, где протоколом № 5 от 13 июля 1930 г. принимается решение «О создании Тувгоскино» (далее - Госкино). В нем основным вопросом становится создание «хозяйственного объединения» в кинофикации THР, с рассмотрением вопроса по пайщикам Госкино с общим паевым взносом в 11500,0 руб.:

- Тувпрофсовету (Шагдыр),

- Тувинценкоопу (Люндуп),

- Минкультуре (Найданов и Санджай),

- Миннархозу (Пунцук) (там же: л. 4).

В этом же документе предусматривалась дальнейшая работа Госкино по кинофикации республики.

Решением протокола заседания коллегии техническое руководство работой Госкино временно возлагалось на т. Бердова (там же: л. 4).

Госкино относилось к ведению Министерства культуры ТНР и основной функцией его было руководство системой мероприятий, обеспечивающих развитие киносети и обслуживания населения. B «Положении о Министерстве Культуры Тувинской Аратской Республики» за 1931 г., в разделе III «Структура Министерства Культуры», в пункте 3 говорится: «Кроме этого в состав Министерства Культуры, на правах обособленных его отделов входят: 1) Тувгиз, Тувздрав, и 3) Государственное фотокино-предприятие /Тувгоскино/ действующее на основе особого положения, утвержденного Советом Министров» (НА РТ, ф. 120, оп.1, д. 1 , л. 2 об.).

В первое время при показе фильмов возникала трудность в описании содержания фильма, т. к. небольшая часть тувинцев понимала русский язык. Так в газете «Новый путь» в 1931 г. вышла заметка под названием «Сделать кино доступным аратам», где указывалось о необходимости выделения переводчика для организации публичного перевода фильма перед показом ${ }^{1}$. Позже, приняв это во внимание, работники культурного отдела разъясняли аратам содержание фильмов, стали готовить переводы на тувинский язык (Моллеров, 1988: 103).

Знаменательным в истории киносети ТНР становится 1931 г., когда начинается создаваться материально-техническая база Госкино, открылся первый деревянный кинотеатр на 150 мест в г. Кызыле и начали функционировать две передвижные установки для выездного обслуживания (НА РТ, ф. 92, оп. 1, д. 54, л. 26) (фото 2).

После объявления скорого приезда кинопередвижки на афишах в сельских поселениях, араты заранее готовились и массово выезжали на место просмотра фильмов. Тувинцы называли кино дириг чурук (живая картина). Вот как об этом вспоминал в газете «Шын» 1985 г. один из жителей БайТайгинского района:

«В конце 20-х годов в нашем районе пошли слухи о сказочных живых картинах. Об этом рассказывали люди, побывавшие в городе Красном... Тогда наш Барыын-Хемчикский район был одним из самых больших районов в Туве (тогда Бай-Тайгинский и Монгун-Тайгинский районы относились к Барыын-Хемчикскому району). Народ нашего района смог увидеть живую картину только в начале марта 1933 г., и тогда кино было без сопровождения звука. К нам приехал один из первых киномехаников из села Аянгаты - Куулар Сенгилдиг... Народу было очень много и негде было показать кино. Тогда Сенгилдиг решил показать кино в кошаре овец... Свет аппаратуры включился и такая была тишина...Сенгилдиг, показывая нам живую картину, время от времени объяснял своими словами. Как восторженно все смотрели живую картину, не

\footnotetext{
${ }^{1}$ Кордова. Сделать кино доступным аратам // Новый путь. 1931. 13 октября, № 70 (317). С. 1.
} 
объяснить словами! Когда кино закончилось, никто даже не пошевелился, чтобы выйти, а сразу начали просить Сенгилдига еще раз показать живую картину... Даже если кино было без звука, этот вечер в кошаре стал незабываемым праздником для всех... Куулар Сенгилдиг в то время был единственным киномехаником во всем Барыын-Хемчикском районе...»1 ${ }^{1}$

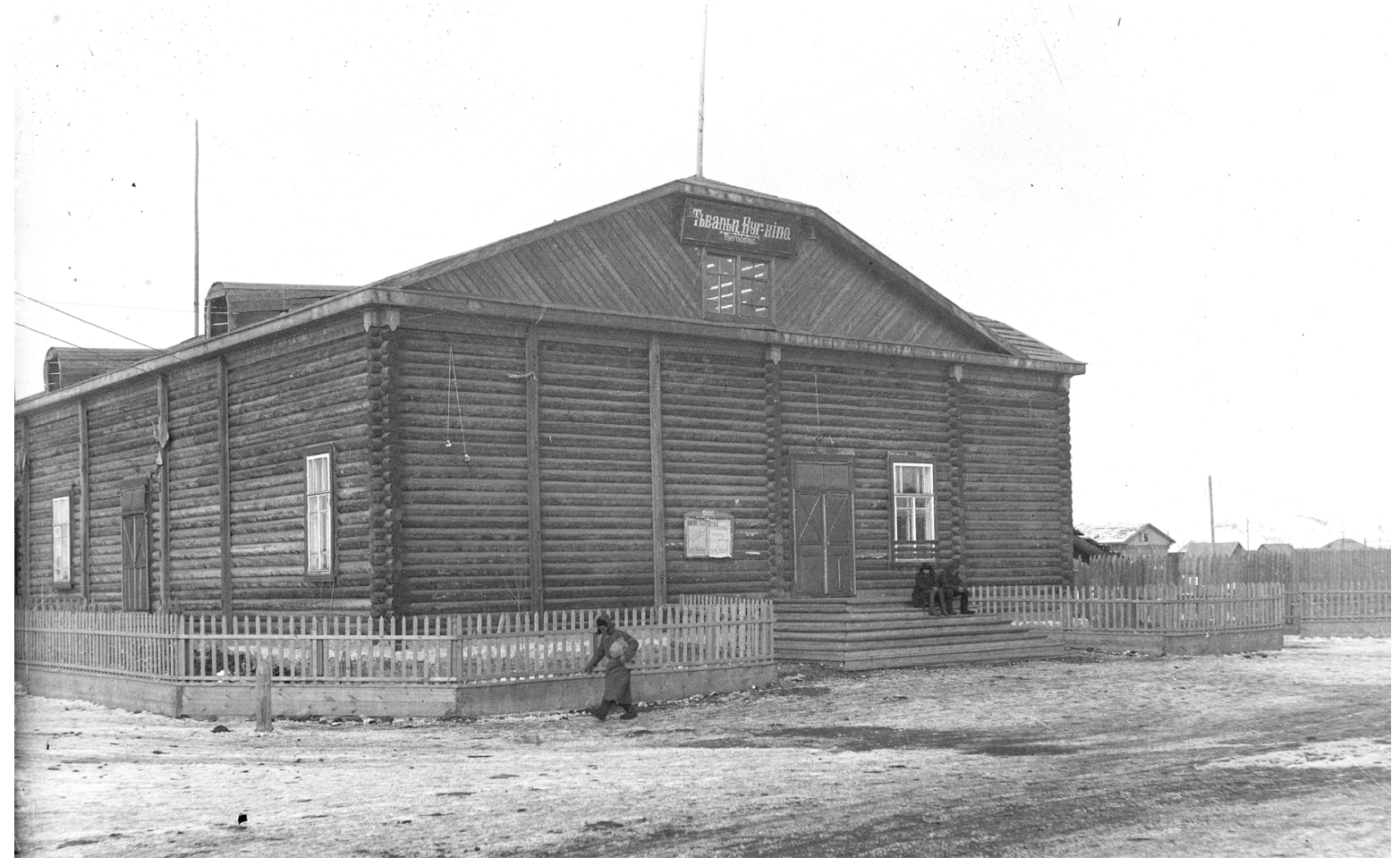

Фото 2. Здание кинотеатра по улице Кочетова. 1937 г. (НМ РТ, КП-11286-1875.

Photo 2. The building of the cinema on Kochetov street, 1937 (NM RT, KP-11286-1875).

Основной проблемой кинофикации того времени становится слабая материально-техническая база, перебои в снабжении и качество кинокартин. Дальнейшее развитие кинофикации в ТНР зависело от расширения киносети и кинопоказов. Учитывая исключительное место кино в идейновоспитательной работе, вопрос кинофикации был представлен в «Пятилетнем плане культурного строительства ТАР (Тувинской Аратской республики) на 1933-1937 гг.» в разделе «Развертывание сети политпросветучреждений» фонда «Министерства культуры ТНР». Даны следующие цифры по развитию сети на ближайшие годы:

- в 1932 г. 1 стационарная киноустановка и 7 передвижных,

- в 1933 г. 2 стационарных и 12 передвижных,

- в 1934 г. 3 стационарных и 16 передвижных,

- в 1935 г. 4 стационарных и 18 передвижных,

- в 1936 г. 5 стационарных и 20 передвижных,

- в 1937 г. 6 стационарных и 22 передвижных (НА РТ, ф. 120, оп. 1, д. 7, л. 19).

Планы республики по кинофикации понемногу начинают воплощаться в жизнь: в Кызыле открывается второй кинотеатр на 320 мест и кинобудка в городском парке культуры, действовавшая в летний период (Кызыл - столица ..., 1964: 48). С открытием летнего сезона работники культпросветучрежений в городском саду им. Гастелло, открытом 5 апреля 1928 г., устраивали массовые гуляния, игры, танцы, концерты. Самым популярным занятием населения на досуге стал просмотр фильмов в кинобудке городского парка.

Таким образом, с середины 1930 гг. в Туве начинает развертываться сеть киноустановок, усиливается материально-техническая база. Показ фильмов населению в основном осуществлялся в сельских клубах, но выездные кинопоказы в сельские поселения были очень востребованы.

${ }^{1}$ Шойгу С. Дириг чурук [Живая картина] // Шын (газета). 1985. 29 июня. С. 3. (На тув. яз.). Перевод А. М. Монгуш. 


\section{НОВЫЕ ИССЛЕДОВАНИЯ ТУВЫ}

www.nit.tuva.asia
№3

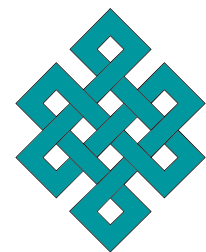

THE NEW RESEARCH OF TUVA 2020

Novye issledovaniia Tuvy

Особое место в истории развития кинофикации занимает дар делегации Советского Союза, прибывшей в 1936 г. на празднование XV годовщины THP: две звуковые кинопередвижки на автомашинах, и одна стационарная киноустановка. Кроме этого, делегация привозит фильм «Чапаев», который сначала показали в г. Кызыле, а потом он демонстрировался во всех кожуунах Тувы (там же: 48) (фото 3).

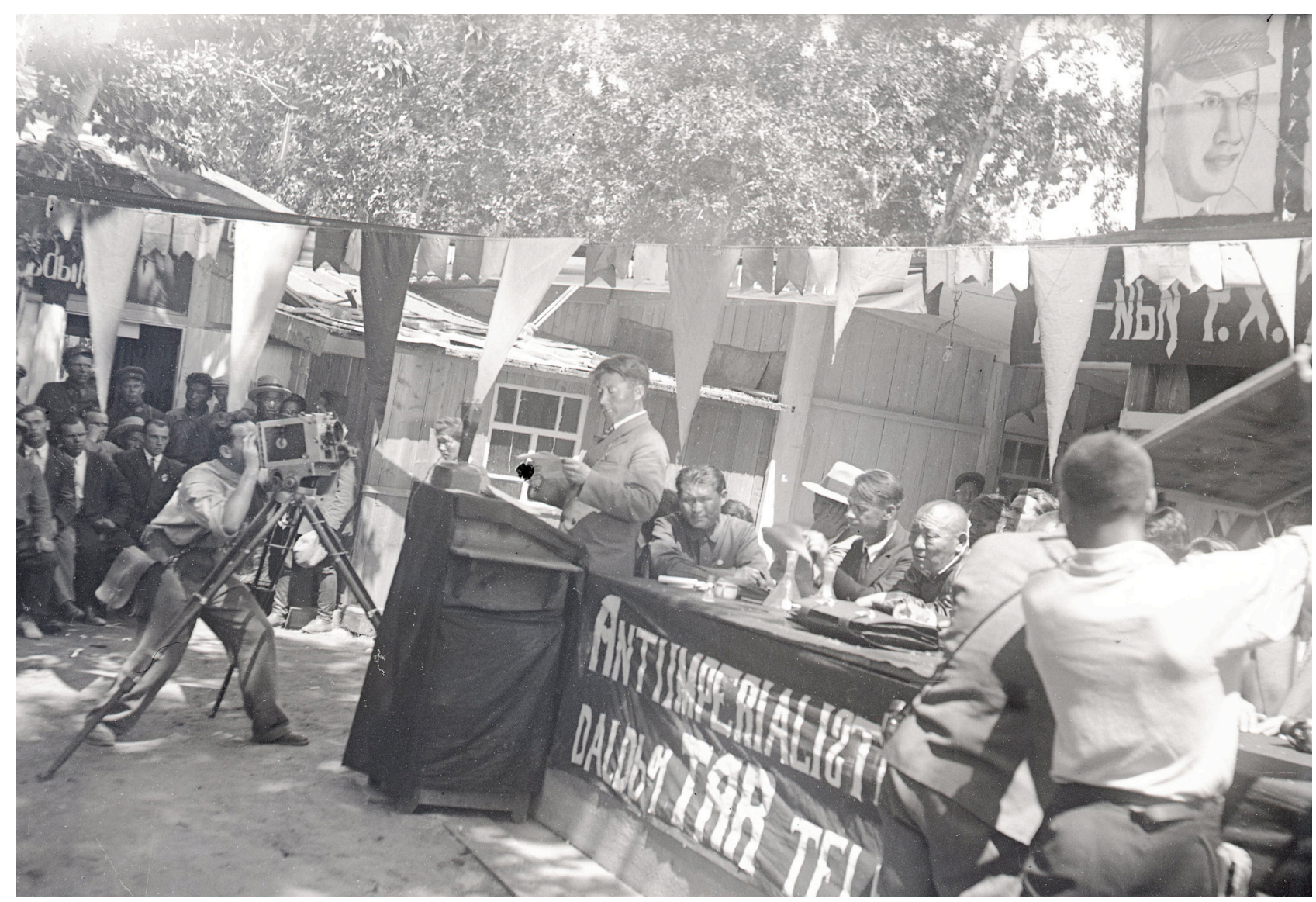

Фото 3. Киносъемка на празднике 15-летия ТНР, 1936 г. ${ }^{1}$ (НМ РТ, КП-11286-1862).

Photo 3. Filming at the celebration of the $15^{\text {th }}$ anniversary of TPR, 1936 (NM RT, KP-11286-1862).

В июльском номере газеты «Вперед» 1936 г. имеется статья о приехавших с делегацией двух кинооператорах, которые «заснимут некоторые наиболее характерные моменты хозяйственной и культурной жизни страны»². Советские кинооператоры создали звуковой документальный киноочерк «Праздник Тувы» (автор-оператор Б. Небылицкий, 1936), созданный на московской студии «Союзкинохроника», также переданный в дар правительству ТНР ${ }^{3}$. В настоящее время в Российском государственном архиве кинофотодокументов (далее - РГАКФД) хранятся 4 кинохроники 1936 г., снятые в THР: «За Саянским хребтом», «Праздник Тувы», «Молодая Тувинская республика» и «Сердце Азии Тува». У первых 3 фильмов режиссером является Н. Б. Небылицкий.

В представленной ниже таблице, из материалов архивного документа, отражено общее количество киноустановок и сельских клубов (таблица 1).

\footnotetext{
${ }^{1}$ Вполне возможно, что на фотографии изображен сам Б. Р. Небылицкий (1909-1972) - советский оператор и режиссёр документального кино, заслуженный деятель искусств РСФСР (1965), лауреат двух Сталинских $(1942,1951)$ и Государственной премии СССР (1969).

${ }^{2}$ Прибыло 2 кинооператора // Вперед. 1936. 21 июля. С. 3.

${ }^{3}$ В НА РТ хранится под названием «15 лет ТНР» (учет кинохроник на сегодня не завершен); см. также Ховалыг, 2020). Копия фильма хранится в Российском государственном архиве кинофотодокументов.
} 
Таблица 1. Количество киноустановок и клубов в Тувинской Народной Республике (НА РТ, ф. 120, оп. 1, д. 7. л. 19). Table 1. The number of film installations and clubs in the Tuvan People's Republic (NA RT, f. 120, op. 1, d. 7, l. 19).

\begin{tabular}{|c|c|c|c|c|c|c|c|}
\hline No & $\begin{array}{c}\text { Наименование } \\
\text { учреждения }\end{array}$ & 1932 г. & 1933 г. & 1934 г. & 1935 г. & 1936 г. & 1937 г. \\
\hline 1 & Клубы & - & 3 & 5 & 6 & 7 & 8 \\
\hline 2 & $\begin{array}{c}\text { Стационарные } \\
\text { киноустановки }\end{array}$ & 1 & 2 & 3 & 4 & 5 & 22 \\
\hline 3 & $\begin{array}{c}\text { Передвижные } \\
\text { киноустановки }\end{array}$ & 7 & 12 & 16 & 18 & 20 & 22 \\
\hline
\end{tabular}

Из таблицы видно, что количество передвижных киноустановок по сравнению со стационарными, с 1932 по 1937 гг. увеличилось в 2 раза. Это объяснялось тем, что коренное население Тувы в основном занималось животноводством и вело кочевой образ жизни и в условиях кочевого образа жизни кино для «подавляющего большинства аратов, план по культурному строительству ТНР предусматривает широкое развитие политпросветучреждений передвижного типа (юрты-передвижки, кинопередвижки, библиотеки передвижки, передвижные ликпункты) ...» (НА РТ, ф. 120, оп. 1, д. 7. л. 18). Как отмечает А. К. Кужугет, передвижная форма работы была наиболее удобной для населения, разбросанного по небольшим аалам (Кужугет, 2006: 195). Мобильные передвижные киноустановки позволяли охватить большое количество населения, учитывая отсутствие во многих районах сельских клубов.

В документе на старотувинской письменности (латинизированной на новотюркской основе - яналифе) по культурному строительству министра культуры ТНР С. Т. Танова на 1 января 1938 г. отражены сведения по наличию киноустановок: стационарная звуковая -1 , передвижная звуковая -2 , немая стационарная - 1, немая передвижная - 8. Всего в 1937 г. в хошуны республики с 37 новыми звуковыми фильмами было произведено 14 выездов с общим кинообслуживанием в 4440 чел. (НА РТ, ф. 92, оп. 1, Д. 49, л. 2).

Укрепление системы киносети ТНР продолжилось и в 1940 г, когда республикой было приобретено 5 передвижных и 5 стационарных звуковых киноустановок (Аранчын, 1982: 232), которые были задействованы в кинотеатрах Кызыла, Турана и Шагонара (Моллеров, 1988: 119). Данные меры существенно повлияли на рост кинопоказов, и в этом году уже состоялось 2416 киносеансов, на которых присутствовало 269 тысяч человек (История Тувы, 2007: 305).

В НА РТ в фонде «Управления Тувинского государственного кино при Совете Министров ТНР» (НА РТ, ф.145; 3 ед. хр., 1940-1944 гг.) хранятся годовые отчеты Госкино с 1940 по 1944 гг., составленные директором Тувгоскино Таржаа, в которых отражается хозяйственная и финансовая деятельность отрасли кино. В инвентаризационном списке имущественных и материальных ценностей, принадлежащих Тувгоскино, на 20 декабря 1940 г. на учете состояло:

- здание кинотеатра по ул. Кочетова, д. 54,

- здание кинобудки (в городском парке),

- здание гаража по ул. Дружбы, д. 94,

- здание под фотографию ${ }^{1}$,

- каменный склад,

- дома и квартиры (всего 7 адресов).

Кроме того, на балансе Госкино также числилось 7 автомашин марки ГАЗ-АА, киноаппаратура и оборудование, различный хозяйственный инвентарь, материалы и топливо (НА РТ, ф. 145, оп. 1, д. 2, л. 64).

В объяснительной записке к годовому отчету за 1940 г. бухгалтер Тувгоскино т. Федотов дает сведения о финансово-хозяйственной деятельности, где доход от центрального кино составляет 108 337,16 акша, от кинопередвижек - 56 447,95 акша, от подсобных предприятий (фотография,

${ }^{1}$ Имеется в виду фотоателье. 
буфет) - 7 243,21 акша. Также из представленных данных видно, что Тувгоскино погашало ссуды, полученные у Тувинценкопа и выделенные на капитальные вложения (строительство склада, приобретение жилого дома, закуп 34 кинокартин). К расходным статьям Тувгоскино относились заработная плата - 35 131,22 акша, расходы по приобретению кинофильмов и киножурналов - 49 916,79 акша и транспортные расходы на содержание автопарка и кинопередвижек. Всего баланс Тувгоскино на 1 января 1940 г. составлял 283037 акша (НА РТ, ф. 145, оп. 1, д. 2, л. 60-62). Отдельным приложением дается список из 128 фильмов, с наименованием, метражом и стоимостью кинокартин.

Рост киносети республики, укрепление ее материально-технической базы становится большим достижением на начальном этапе кинофикации Тувы. Вместе с тем, с расширением кинофикации в республике назревает острая проблема обеспечения кадрами, решение которой осуществлялось в двух направлениях: путем организации краткосрочных курсов и привлечения квалифицированных специалистов из Советского Союза. В середине 1930-х гг. первые тувинцы прошли обучение работе на кинопередвижках и были направлены в родные кочевья. Тувинцы-киномеханики со своими передвижками с немыми фильмами проделывали большую просветительскую работу среди аратов, живущих в отдаленных труднодоступных местностях (Аранчын, 1982: 232).

Правительство ТНР оказывало большое внимание подготовке кадров и повышению квалификации, о чем свидетельствуют следующие архивные документы: в постановлении XVIII сессии Малого Хурала THP «О задачах ТНР на 1937 г. по хозяйственному и культурному строительству», в п. 7 указывается на необходимость обучения киномехаников (НА РТ, ф. 93, оп. 1, д. 7, л. 5) и в пятилетнем плане культурного строительства ТНР на 1932-1937 гг. ставился вопрос о потребности в киноработниках и организации краткосрочных курсов для киномехаников (НА РТ, ф. 109, оп. 1, д. 5, л. 13).

Так, в архивных документах, в «Тезисах о культурном строительстве ТАР» от 1935 года, в докладе министра культуры Тастай-оола отмечается нехватка специалистов кино: «кинопередвижки не обеспечены работниками. В настоящее время при кинофотообъединении проводятся курсы-аратов для подготовки их в качестве таких работников. Имеются недостатки в снабжении киноустановок фильмами (поступают одни и те же по несколько раз в году, низкая техническая годность)» (НА РТ, ф. 1, п. 1, д. 1581, л. 16об.). В этом же деле в документе под заголовком «Сведения по культурным вопросам» в разделе «Политпросвет сеть» в пункте 4 указано, что «подготовлено аратов для кино-передвижек 8 человек (из них уже три выехало в хошуны» (НА РТ, ф. 1, оп. 1, д. 1581, л. 76).

Стоит отметить, что работа киномехаников требовала не только знаний по киноделу, но и умение вести агитационную работу. Зачастую работникам партийных организаций поручалось привлекать грамотную, активную молодежь в ряды киномехаников, поскольку одной из основных функций кинофикации является контроль в области репертуарной политики и работа со зрителем. Учитывая то, что основной упор культурной политики руководство ТНР связывало с развитием тесных отношений с Советской Россией, влияние новой революционной культуры касалось и сферы кино. В СССР кино имело четко ориентированную идеологическую направленность, создание его регулировалось со стороны партии, руководства Советов. Поэтому репертуар большинства функционировавших киноустановок в ТНР этого периода отвечал задачам руководящей партии - через киноискусство убедить тувинцев в правильности выбора социалистического пути развития.

Так, в клубе советских граждан Кызыла одними из первых фильмов были «Юные пионеры», «Празднование 1 мая в Минусинске», «Приезд тувинской делегации в СССР», «Место ссылки Ленина» (Моллеров, 1988: 103), «Мать» (Менхен-Хельфен, 2007: 249), «В тылу у белых» и «Красные партизаны»1.

Тувинцы, особенно молодое поколение, очень полюбили советское киноискусство. «С неослабевающим интересом и большим душевным волнением араты смотрели фильмы "Броненосец “Потемкин”, “Чапаев”, “Ленин в Октябре”, “Мы из Кронштадта”, “Зангезур”, “Айгюль”, “Дума про казака Голоту”, “Потомок Чингисхана”, “На границе”, “Тринадцать”, “Герой Гонгор”, “Граница на замке”. Только в 1940 г. на 2416 киносеансах побывало 269 тыс. человек, т. е. каждый взрослый человек Тувы посетил кино 13 раз. Советские фильмы оказывали сильное воздействие на тувинцев, воспитывали их в духе верности идеям Великого Октября, искренней привязанности и горячей любви к СССР», - писал Ю. Л. Аранчын (Аранчын, 1982: 232).

\footnotetext{
${ }^{1}$ Титенков А. Первое кино в Туве // Тувинская правда. 1979. 24 июля. С. 3.
} 
К примеру, в 1941 г. был снят документальный фильм «Страна голубой реки» (автор-режиссер Ф. Киселёв, операторы В. Соловьев и В. Фроленко, текст читал Ю. Левитан), раскрывающий о первых успехах социалистического развития в Туве, переход традиционной культуры на новый. Оригинал фильма хранится в РГАКФД (учетный номер № 4917, производственный № 1-5535), копия фильма - в фондах НА РТ. Все фильмы, поступавшие в прокат в 1930 гг. в ТНР создавались на крупных советских киностудиях: «Мосфильм», Киностудия им. А. М. Горького, «Ленфильм» и др.

По архивным документам из фонда «Министерства иностранных дел ТНР» (НА РТ, ф. 100, 315 ед. хр., 1922-1944 гг.) видно, что основным связующим звеном ТНР с советскими организациями, осуществлявшими торговый и культурный обмен с иностранными государствами, были Всесоюзное объединение по торговле с Монгольской и Тувинской народными Республиками (далее - Совмонгтувторг) и Всесоюзное общество культурной связи с заграницей (далее - ВОКС). Совмонгтувторг и ВОКС снабжали ТНР немыми и звуковыми кинофильмами, занимались вопросами проката советских фильмов в ТНР, культурным обменом между государствами.

В этом фонде в деле «Договор между «Совмонгтувторгом и “Тувгоскино” о поставке для “Тувгоскино” звуковых и немых кинофильмов для проката их на территории ТАР» хранится договор между Совмонгтувторгом и ТНР о поставке в течение 1938 г. 35-ти полнометражных кинофильмов (выпуска 1936-1938 гг.) и не менее 30 тысяч метров документальных и хроникальных фильмов производства кинопромышленности СССР общей стоимостью 26000 рублей (НА РТ, ф. 100, оп. 1, д. 177, л. 1-4).

В другом деле, озаглавленном «Переписка с полномочными представителями ТНР в СССР и МНР, советскими учреждениями и организациями о культурной связи с заграницей» хранится письмо Председателя Совета Министров и Министра иностранных дел ТНР Байыра председателю ВОКС О. Д. Каменевой от 17 сентября 1940 г., в котором сообщается:

«За время своего пребывания в Великом Советском Союзе в июле месяце этого года, при горячей помощи и братской заботе соответствующих организаций Советского Союза, я имел счастье заложить начало непосредственной связи нашей страны с ВОКСом... В целях наиболее полного практического осуществления нашей связи я хотел бы просить ВОКС о следующем: ... 2. На основе нашей договоренности в порядке подарка прислать нам следующие советские кинофильмы: “Великий гражданин” (2-ая серия), “Сорочинская ярмарка”, “ВСХВ” (хроника), “Встречный”, “На Дунае”, “Большой вальс” и ряд хроникальных короткометражных фильмов героического содержания (“Праздник Сталинской авиации в Советской Эстонии, Латвии и Литве” и другие) и дать к ним наряду с русским и тувинский текст» (НА РТ, ф. 100, оп. 1, д. 215, л. 18).

В архивных документах НА РТ имеется договор на пяти листах между Тувгоскино и Всесоюзной государственной конторой по киноэкспорту и киноимпорту («Союзинторгкино»), заключенный в январе 1941 г., о прокате 35 художественных, 5-документально-художественных, 25000 метров- хроникально-документальных и киножурналов на общую сумму 71000 рублей (НА РТ, ф. 100, оп. 1, д. 258 , л. 1-6). По данному документу можно говорить об объеме, востребованности и окупаемости кинопродукции, поставляемой в Туву.

В начале 1940 гг. органы власти республики обращали большое внимание на работу Тувгоскино, на его условия работы, исполнение утвержденных планов. Из архивных документов 1941 г. мы узнаем, что после доклада директора Тувгоскино Таржаа о деятельности учреждения, Совет Министров принимает специальное постановление. В документе, написанном на яналифе «Kyr kinonun azblьnьn tugajbnda TAR sajbttar cobulelinin toktaalь» («O работе Госкино»), отмечаются недостатки в работе учреждения, а также указываются конкретные меры по улучшению финансово-хозяйственной деятельности (фото 4-6).

К концу 1930-х - начале 1940 гг. кино становится любимым культурным и познавательным времяпровождением тувинцев. Для молодой республики это был не только досуг населения, но и действенный метод формирования нового сознания и поведения аратов. Архивные документы подтверждают, что кинофикации ТНР предшествовала трудная работа по созданию материально-технической базы, постепенной замене киноустановок на звуковые, более модернизированные. Так как территории государства были большие и население проживало разрозненно, для обеспечения всех труднодоступных хошунов, кочевий аратов приходилось обучать новые кадры, искать доступные способы передвижения киноустановок. Профессия киномеханика, совершенно новая для Тувы, стала очень уважаемой в народе, а кинофильмы прочно вошли в жизнь кочевников. 


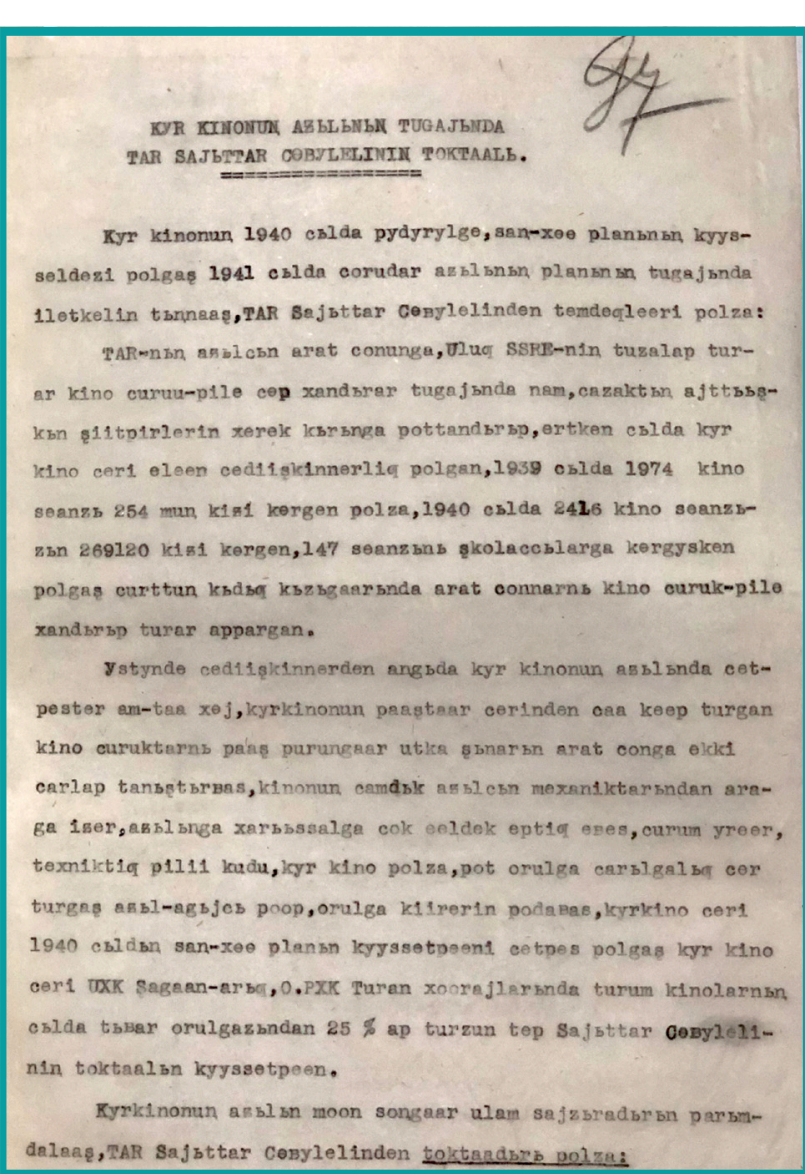

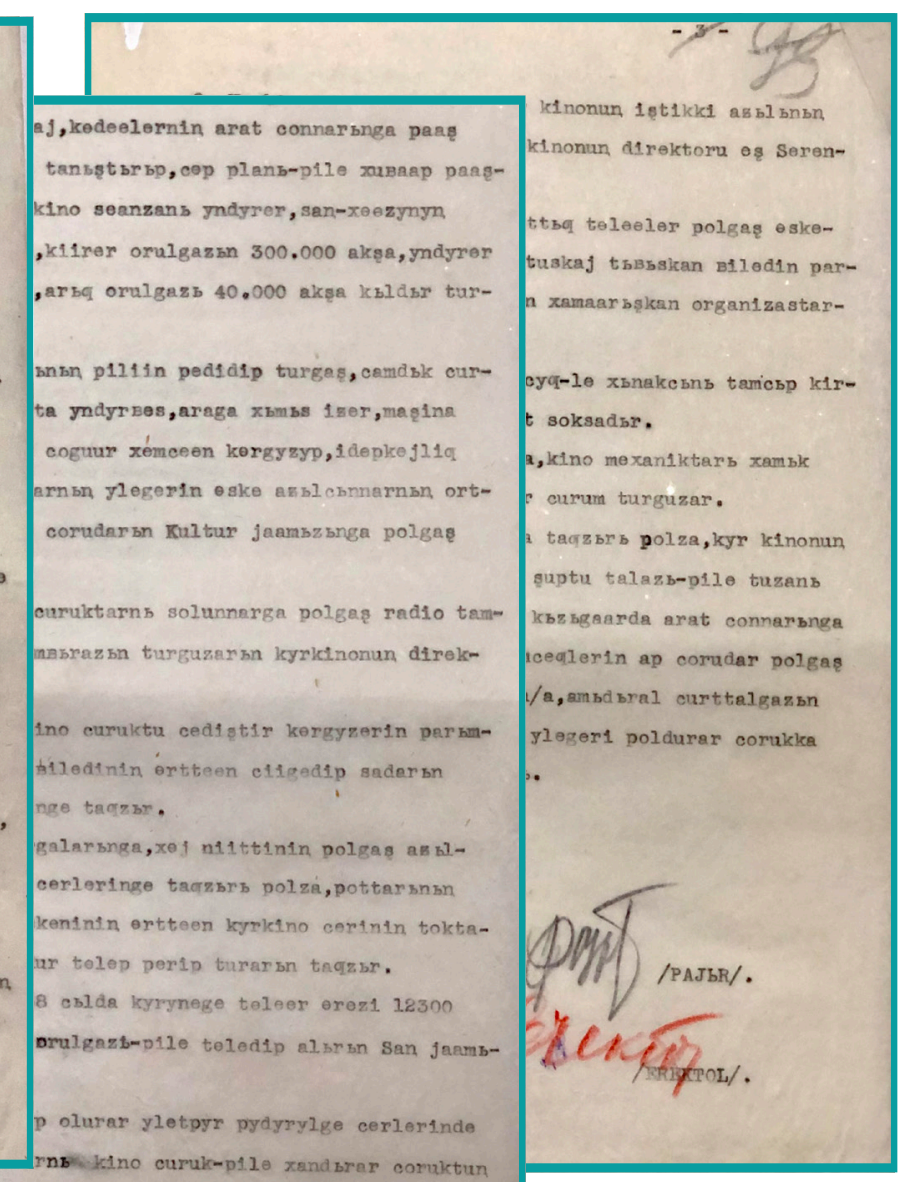

cingulazsn parbalaleas, llarbn Aldsn uurgajbnda keser kinomun

apparadsn Xarael aldsn

Фото 4-6. Постановление Совета Министров ТНР «О работе Госкино» (НА РТ, ф. 92, оп. 1, д. 916, лл. 111-113).

Photos 4-6. Resolution of the Council of Ministers of the TPR "On the State Cinema Office" (in Latin script), 1941

(National Archives of the Republic of Tuva, f. 92, op. 1, d. 916, 1l. 111-113).

\section{Киносеть ТНР в военное время}

Развитие киносети Тувы в военное время также нашли отражение в архивных документах и газетных подшивках Национального архива Тувы. Ценные сведения по системе кинофикации содержатся в фондах «Совета министров ТНР» (НА РТ, ф. 92, 1298 ед. хр., 1921-1944 гг.), «Президиума Малого хурала ТНР» (НА РТ, ф. 93, 561 ед. хр., 1921-1944 гг.), «Управления Тувинского государственного кино при Совете Министров ТНР» (НА РТ, ф. 145, 3 ед. хр., 1940-1944 гг.).

Тува, как одно из первых государств, предложивших свою помощь Советскому Союзу, всецело перестроилась на военный лад. С первых же дней Великой Отечественной войны отрасль кино, как и все учреждения культуры ТНР, нацелилась для решения военных задач. Изменения коснулись всей системы киносети, репертуарной политики и кинопроката республики. Свой вклад в культурную трансформацию тувинского народа внесли и культпросветучреждения: к 1944 году в Туве работали 26 клубов, 30 красных уголков и 47 библиотек (Анчима, 1970: 59). Работники Госкино, после показа фильмов проводили беседы, кинолектории для зрителей, читали доклады и сообщения о последних новостях с войны. Основное место в репертуаре кино стали занимать ленты хроникально-документального жанра, отражающие героические события военного времени.

В Туве в это время при содействии советских кинооператоров сняты документальные фильмы о вкладе тувинского народа в борьбе с фашизмом, о тувинских добровольцах, о подарках Красной Армии: «Хроника об участии тувинских добровольцев в Великой Отечественной войне, о помощи Тувы фронту» (1941 г.), «Хроника о поездке на фронт делегации Тувинской Народной Республики третьим эшелоном подарков» и др. 
Приезд тувинской делегации в апреле 1942 г. во главе с генеральным секретарем ЦК ТНРП С. К. Тока стал основой документального фильма «Приезд тувинской делегации», снятой операторами Т. Бунимовичем и М. Беровым. Уникальным является то, что в НА РТ сохранился архивный документ Указ Президиума Малого Хурала ТНР от 31 марта 1942 г. - о награждении Орденом Республики ТНР командующего Западным фронтом, Героя Советского Союза, генерала армии Г. К. Жукова и руководящего командного состава Красной армии СССР (НА РТ, ф. 93, оп. 1, д. 348, л. 4). В данном кинодокументе запечатлена встреча делегации в штабе командования с Г. К. Жуковым, посещение освобождённых воинских частей, г.г. Истра и Волоколамск (сам кинодокумент хранится в РГАКФД, учетный № 5264). В газете «Тувинская правда» вышла заметка о делегации ТНР в Москву в 1942 г. ${ }^{1}$

Кинохроника 1943 г. под названием «Тува», снятая кинооператором А. Г. Щекутьевым Центральной студией кинохроники, имеет продолжительность 12 минут и сопровождается закадровым голосом. Действие хроники начинается с железнодорожного вокзала в Москве, где тувинскую делегацию встречают представители советского командования во главе с генерал-полковником О. И. Городовиковым и чрезвычайным послом ТНР в СССР О. Мандараа. В ходе поездки делегация передает эскадрилью боевых самолётов, построенных на средства собранных тувинским народом, затем С. К. Тока вручает высшие награды ТНР генерал-полковнику М. А. Рейтеру и др.

Данный кинодокумент на электронном носителе хранится в фондах НА РТ (фото 7-9).
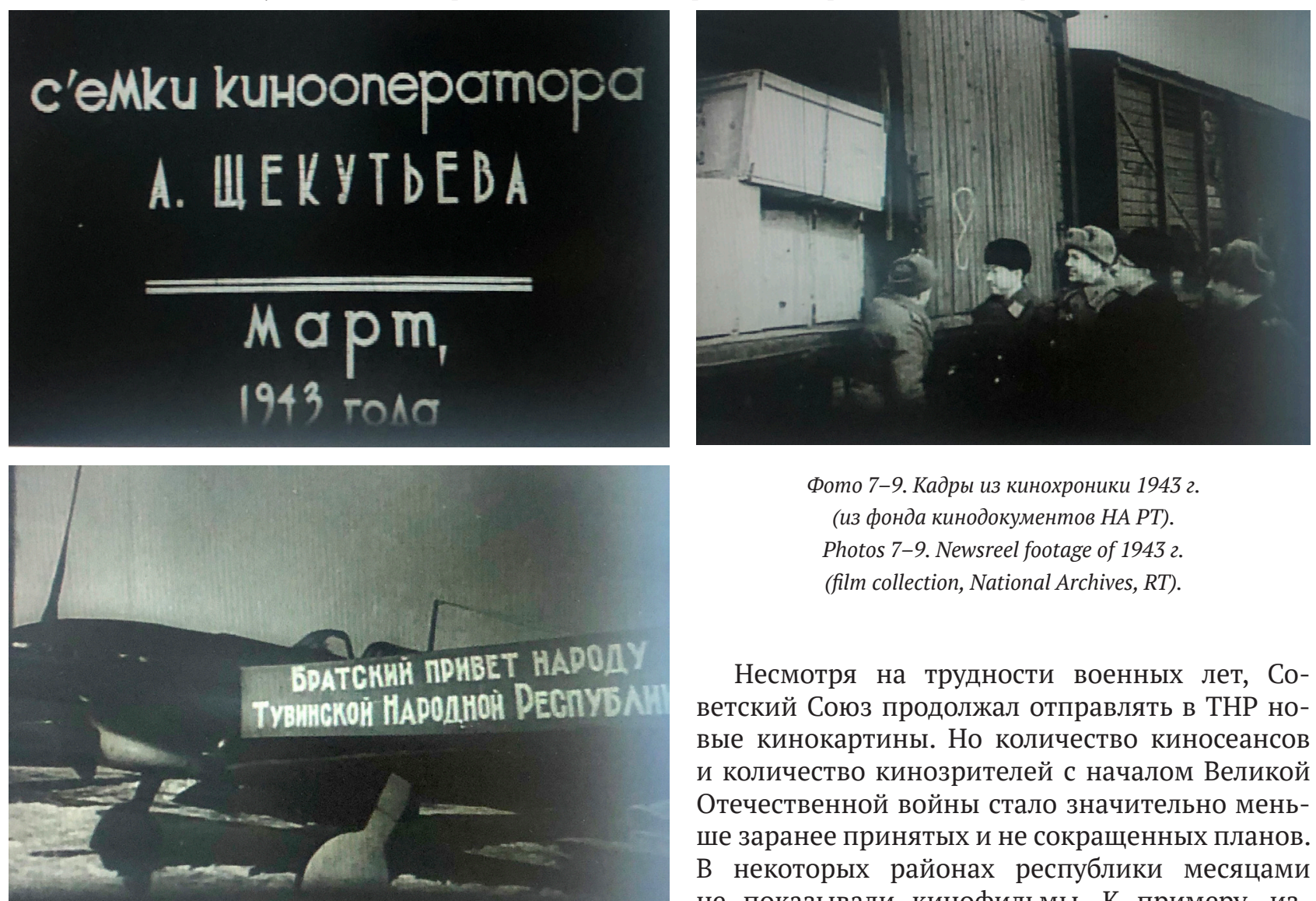

Фото 7-9. Кадры из кинохроники 1943 г. (из фонда кинодокументов НА РТ). Photos 7-9. Newsreel footage of 19432. (film collection, National Archives, RT).

Несмотря на трудности военных лет, Советский Союз продолжал отправлять в ТНР новые кинокартины. Но количество киносеансов и количество кинозрителей с началом Великой Отечественной войны стало значительно меньше заранее принятых и не сокращенных планов. В некоторых районах республики месяцами не показывали кинофильмы. К примеру, изза отсутствия горючего топлива и простоя электростанций в 1942 г. не выполнили план Дзун-Хемчикский, Пий-Хемский и Барун-Хемчиский районы (НА РТ, ф. 92, оп. 1, д. 1170, л. 2). Это подтверждается словами Сиин-оола Лакпаевича Оюна, первого профессионального тувинского режиссера Тувы: «В годы войны кино мы смотрели не часто, примерно один раз в месяц или даже месяцами не смотрели. Помню, как мы смотрели один и тот же фильм “Чапаев” несколько раз...»².

${ }^{1}$ Прибытие делегации ТНР с подарками для Красной Армии в Москву // Тувинская правда. 1942, 1 мая. С. 2.

${ }^{2}$ Информант - Сиин-оол Лакпаевич Оюн, 1934 г. р.; место рождения - г. Москва; место и дата проведения интервью - г. Кызыл, 21.07.2020 г. 
Другой проблемой была слабая материально-техническая база Управления «Тувгоскино». Так, в годы Великой Отечественной войны на территории ТНР насчитывалось всего 5 стационарных звуковых установок (ТОмП-4, К-Б-1, УСУ-9, УСУ-3 1936-1938 гг. выпуска), 9 звуковых кинопередвижек (К-25, 1936-1938 гг. выпуска) и две немые кинопередвижки (Г03 1929 г. выпуска). Стационарные киноустановки имелись в административных центрах крупных районов: Шагонар, Туран, Чадан, Байгак и Кызыл-Мажалык (НА РТ, ф. 92, оп. 1 , д. 1170, л. 9). Их техническое состояние было неудовлетворительным, и многие из них нуждались в капитальном ремонте. Кино-ремонтной мастерской в республике не было, и это приводило к частым простоям киноустановок. Технический износ большинства запасных частей и деталей стационарной и передвижной киноаппаратуры и передвижных электростанций колебался от 40 до $70 \%$ из-за отсутствия с 1941 г. ряда запасных деталей (НА РТ, ф. 92, оп. 1, д. 1170, лл. 9, 10).

Безусловно, все это сказывалось на выполнении финансового плана киносети. Часто получалось, что кинопередвижная сеть не выполняла задание и не удовлетворяла потребность населения в просмотре фильмов. Например, в 1942 г. работниками передвижной сети по всей республике было показано в среднем 152 сеанса в месяц при наличии 127 населенных пунктов (НА РТ, ф. 92, оп. 1, д. 1170, л. 10). Кинопередвижная сеть не выполняла финансовый план, плановых показателей не достигали стационарные установки в Шагонаре, Туране, Чадане и Барун-Хемчикском районе (там же: лл. 1, 2).

По отчетным данным Тувгоскино на 1 января 1944 г. видно, что количество гужепередвижек преобладает над автопередвижками. В автопарке числилось всего 3 автомашины марки ГАЗ-АА и 4 лошади для перевозки оборудования (НА РТ, ф. 145, оп. 1, д. 1, л. 35). Правительство республики специальными распоряжениями всячески старалось поддерживать киносеть и обязывало всем предприятиям предоставлять попутный и гуже-транспорт для кинопередвижек. Зачастую работникам одной кинопередвижки приходилось выезжать на долгое время для кинообслуживания от трех до пяти сумонов за одну поездку. Иногда приходилось нести киноаппаратуру на себе.

Работа на передвижках с гужевым транспортом требовала от киномехаников не только мастерства с оборудованием и физической выносливости, но и умения обращения с животными. Так, в документах по личному составу Тувгоскино имеются приказы об увольнении работников, которые не справлялись или отказывались от работы с лошадьми, а также об объявлении выговора за плохой уход за лошадьми (НА РТ, ф. 145, оп. 1, д. 1, лл. 81, 82).

Одной из проблем Тувгоскино, как и других учреждений ТНР, была нехватка площадей. Отсутствие фильмохранилища сказывалось на хранении бобин и качестве фильмов, о чем свидетельствуют архивные документы 1942-1943 гг., когда 211 полнометражных фильмокопий хранились в абсолютно непригодном помещении (НА РТ, ф. 92, оп. 1, д. 1170, л. 10). Несмотря на все материально-технические 
издержки, в 1943 г. система кинофикации республики продолжала обслуживать население, и даже перевыполнила план на 15\% (там же:л.4). С течением времени решение организационных и технических проблем киносети позволило работникам четко выполнять поставленные перед ними задачи. На киносеть Управления «Тувгоскино», состоящую из 17 человек, было возложено обслуживание 95000 населения ТНР проживающего в 16 хошунах со 127 населенными пунктами (там же: л. 9).

С развитием киносети стало больше внимания уделяться работе со зрителем. Для решения этой задачи был рассмотрен вопрос по урегулированию цен в интересах кинозрителя, принят приказ Управления Госкино № 10 от 7 февраля 1944 г., которым вводится единая ценовая политика на кинобилеты в г. Кызыле, стационарных кинотеатрах и кинопередвижках. Так, сеансы для взрослых в г. Кызыле стоили от 1 до 1,25 акша в зависимости от времени показа, детские сеансы - по 50 коп., организованные посещения учащихся - по 30 коп. за билет. В кинопередвижках цена сеансов устанавливалась в 1 акша, для детей - 30 коп., за обслуживание учащихся интернатных сумонных школ за счет средств школ - 20 коп. Данная мера способствовала увеличению роста посещений кино (НА РТ, ф. 145 , оп. 1 , д. 1 , л. 88) (фото 10).

В фонде «Управление Тувинского государственного кино при Совете Министров ТНР» хранится план за 1944 г., в котором видно поквартальное распределение кинопередвижек между точками кинопроката (таблица 2).

Таблица 2. План на 1944 г. для Центрального кино и хошунных киноустановок, 1944 г. (HA PT, ф. 145, on. 1, д. 3, л. 3).

Table 2. Planned number of cinema installations, for CentralKino and the khoshuuns

(National Archives RT, f. 145, op. 1, d. 3, l. 3).

\begin{tabular}{|c|c|c|c|c|c|}
\hline $\begin{array}{c}\text { Наименование } \\
\text { киноточек }\end{array}$ & І квартал & ІІ квартал & IІІ квартал & IV квартал & Общая сумма \\
\hline г. Кызыл & 205 & 205 & 205 & 205 & 820 \\
\hline г. Туран & 45 & 45 & 45 & 45 & 180 \\
\hline г. Шагонар & 45 & 45 & 45 & 45 & 180 \\
\hline г. Кызыл-Мажалык & 41 & 42 & 41 & 41 & 165 \\
\hline г. Чадан & 41 & 42 & 41 & 41 & 165 \\
\hline Всего & 377 & 379 & 377 & 377 & 1510 \\
\hline
\end{tabular}

Необходимо отметить, что помимо строительства культурных учреждений в республике повсеместно решались вопросы с профессиональными кадрами. Вызванная войной острая потребность в квалифицированных специалистах наблюдалась во всех культурно-просветительных учреждениях Советского Союза, в том числе в ТНР.

Наибольшая потребность в киноработниках ощущалась в отдаленных районах, где разъездной характер работы и низкая заработная плата приводили к текучести кадров. Руководством ТНР проводилась большая работа по приглашению квалифицированных специалистов из СССР в республику, которые даже в годы войны помогали молодому государству. Об этом свидетельствует письмо министра культуры ТНР уполномоченному послу ТНР об отправке в Туву врачей и других специалистов Министерства культуры, а также выделении киноаппаратуры и т. д. (НА РТ, ф. 120, оп. 1, д. 19, лл. 2-6). Проблема с кадрами решалась в основном отправкой студентов на учебу в СССР, а также в Монгольскую Народную Республику. Чаще всего в целях ликвидации кадрового дефицита в ТНР работников отправляли на краткосрочные курсы. В начале 1944 г. на курсах обучались 10 киномехаников (НА РТ, ф. 92, оп. 1, д. 1170, л. 5) (фото 11).

В Советском Союзе система ученичества функционировала достаточно эффективно и набирала обороты. Как отмечают Н. П. Храмкова и В. В. Заводчиков, система ученичества (наставничества) позволяла с наименьшими затратами и достаточно быстро обучить новые кадры (Храмкова, Заводчиков, 2017). Управление «Тувгоскино» также применяло в работе систему ученичества. Одними из первых тувинских киномехаников были Сенди Кыргыс, Чимит-оол Ондар, Сенгилдиг Куулар (Анчима, 1970: 67), которые прошли через такую систему обучения. Из воспоминаний д-ра геогр. н. С. С. Курбатской: 
«В Эрзинском районе киномехаником работал Сенди Кыргыс. У него было прозвище среди народа "Кино Сенди”. Помню, он приезжал к нам не часто, примерно 1 раз в месяц. Когда он приезжал в наше село, это был целый праздник для нас! Весь народ от мала до велика все бежали к нему смотреть кино» ${ }^{1}$.

Значительно возросла роль киномеханика в условиях военного времени. Естественно, помимо своего основного предназначения, он также становился агитатором и пропагандистом патриотических идей. Работники Тувгоскино всячески старались поддерживать киноработников в их профессиональном росте. Следуя примеру Советского Союза ЦК Профсоюза и Управление «Тувгоскино» с 1943 г. начали проводить социалистические соревнования работников кино. Так, победителями в республиканских соревнованиях по всем показателям работы кино в 1943 г. были признаны: Тере-Хольская кинопердвижка (заведующая Байгара Дыклаа), которой было присуждено переходящее Красное Знамя Совета Министров ТНР и ЦК ТНРП с выдачей премии I степени, кинопередвижкам Дзун-Хемчикского, Овюрского, Сут-Хольского хошунов (т. Ондар Чимит-оол) были выданы денежные премии II степени². В последующие годы соревнования продолжались, становясь своеобразным стимулом в работе, о чем свидетельствует приказ Тувгоскино от 8 апреля 1944 г., где за первое место была награждена Эрзинская передвижка, с денежной премией в 600 р., за второе место - передвижки Дзун-Хемчикского, Овюрского, Сут-Хольского кожуунов в размере 300 р. (НА РТ, ф. 145, оп. 1, д. 1, л. 73).

Благодаря слаженной работе коллектива Тувгоскино и введенной системе материального поощрения, производственно-финансовый план первого полугодия 1944 г. был перевыполнен и даже наметился рост при сравнении с предыдущими годами (НА РТ, ф. 92, оп. 1, д. 1170, л. 10).

Отдельное место кино отводилось во время весенне-полевых работ, окотных, сельхозкомпаний. Так, в документах Тувгоскино 1944 г. есть сведения, когда по строгому указанию Правительства ТНР в районные центры хошуунов направлялись 10 кинопередвижек:

1. Бай-Тайга - кинопередвижка Семис-оола,

2. Монгун-Тайга - немая кинопередвижка Семис-оола,

3. Чадаан - кинопередвижка Абрамкина,

4. Овюр - кинопередвижка Седен-оола,

\footnotetext{
${ }^{1}$ Информант - Курбатская Светлана Суруновна, 1937 г. р.; место рождения - с. Эрзин Эрзинского кожууна Тувинской АССР, место и дата проведения интервью - г. Кызыл, 15.07.2020 г.

${ }^{2}$ В ЦК Профсоюза и Управления Тувгосино // Тувинская правда (газета). 1944, № 31, 12 апреля. С. 5.
} 
5. Улуг-Хем - кинопередвижка Байыр-оола,

6. Танды - кинопередвижка Путинцева,

7. Тес-Хем - кинопередвижка Тыкылаа,

8. Каа-Хем - кинопередвижка Антреева,

9. Сут-Холь - кинопередвижка Нукиса,

10. Колхозы - кинопередвижка Торонина (НА РТ, ф. 145, оп. 1, д. 1, л. 71).

Следует добавить, что на первом этапе становления киносети в ТНР закладывалась основа по подготовке профессиональных кадров в области кино. Впоследствии, когда ТНР вошла в состав СССР (11 октября 1944 г.), отрасль кинопроката пополнялась профессиональными специалистами. Помимо кинопроката и показа фильмов, в республике стали снимать фильмы с участием тувинских актеров.

На развитие системы кинофикации в ТНР по-прежнему оказывал влияние СССР, где военная тема в репертуарной политике стала ведущей и централизованно определялся Управлением кинофикации и кинопроката. В основе его деятельности лежали установки, озвученные И. В. Сталиным: «кино обладает исключительными возможностями воздействия на массы, оно мобилизует советских людей, рабочих, крестьян, интеллигенцию на еще более эффективную помощь фронту в борьбе с фашистскими варварами. Полностью и до конца использовать эту огромную силу - кино, в интересах нашего дела завоевания победы над врагом - вот задача ...., которую должны разрешить работники кинофикации и кинопроката» (Сталин, 1953: 63).

На киностудиях Советского Союза шла напряженная работа по созданию полнометражных лент, картин. Съемкой фильмов на фронтах, в местах боевых действий занимались более 200 кинооператоров страны. В целом за годы войны было снято 103 художественных фильма, из них более 60 - непосредственно о Великой Отечественной войне (Галкин, 2009: 23). В условиях войны это был небывалый труд кинооператоров, режиссеров, сценаристов.

По всей территории Советского Союза, а также в ТНР, фильмы оказывали большое влияние на патриотическое воспитание народа. В газетном фонде НА РТ за 1942 г. имеются сведения о показе на киноэкранах республики, следующих фильмов: «Дочь моряка» $(1941 \text { г })^{1}$, «Ленинград в борьбе» $(1942 \text { г. })^{2}$, «Черноморцы» $(1942 \text { г. })^{3}$, «Концерт фронту» (1942 г. $)^{4}$ и др. С мая месяца на киноэкранах

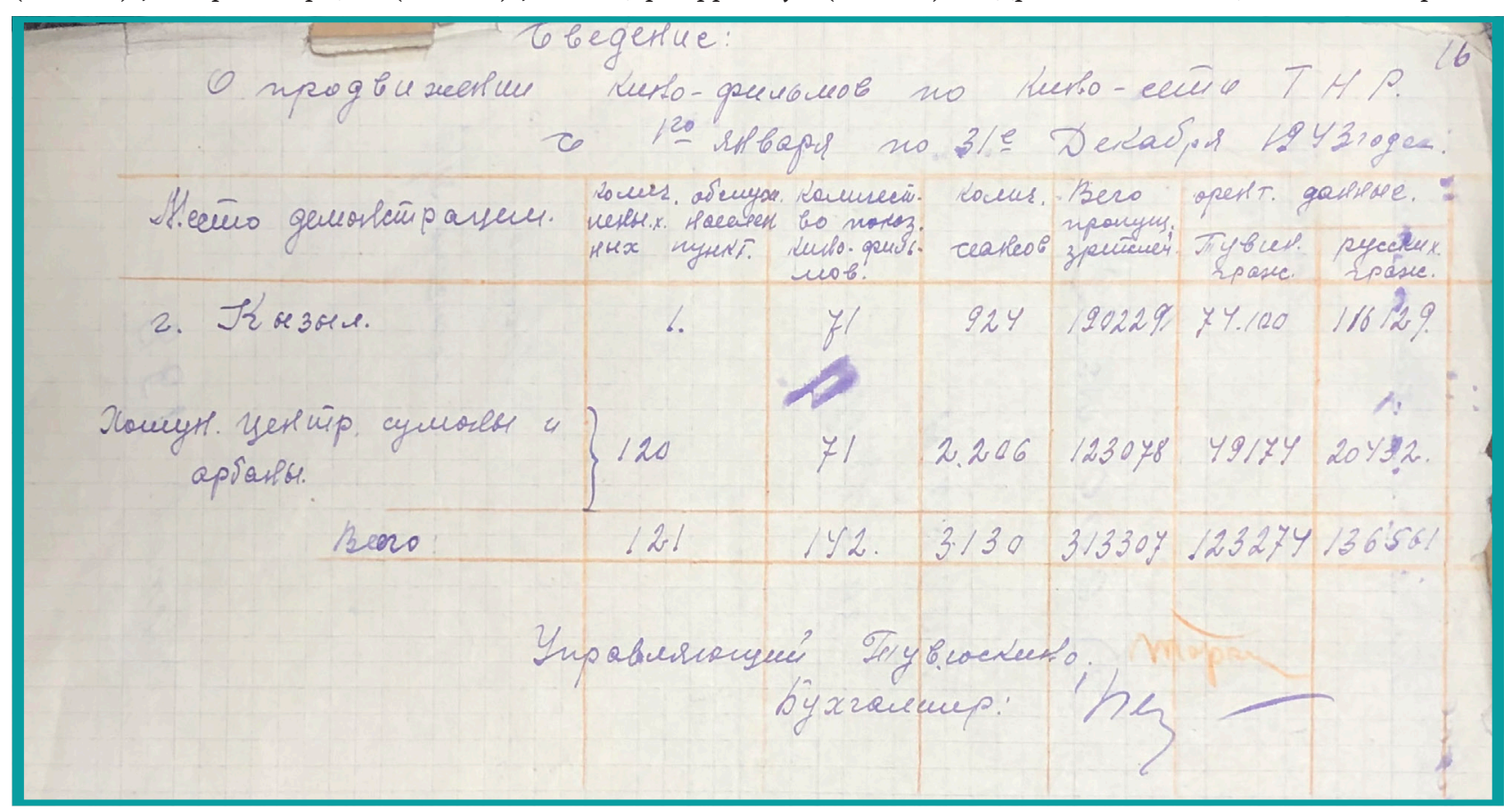

Фото 12. Сведения о продвижении кинофильмов по киносети ТНР за 1943 г. (НА РТ, ф. 145, оп. 1, д. 1, л. 1).

Photo 12. Information on the promotion of films on the TPR movie network, 1943 (NA RT, f. 145, op. 1, d. 1, l. 1).

\footnotetext{
${ }^{1}$ Тувинская правда. 1942. № 87. 2 сентября. С. 4.

${ }^{2}$ Тувинская правда. 1942 . № 80.13 августа. С. 8.

${ }^{3}$ Тувинская правда. 1942. №104. 11 октября. С. 6.

${ }^{4}$ Тувинская правда. 1942. №135. 25 декабря. С. 4.
} 
республики была демонстрирована кинокартина «Оборона Царицына» $\left(1942\right.$ г.) ${ }^{1}$, созданная в условиях войны лауреатами Сталинской премии I степени братьями Васильевыми. В декабре этого года в Туве был широко показан документальный фильм «День войны» $(1942 \text { г.) })^{2}$, раскрывающий героическую борьбу советского народа против захватчиков. За 2 дня показа в столице, фильм, с большим восторгом и волнением посмотрели 2800 человек ${ }^{3}$. Вышеуказанные 2 фильма собрали наибольшее количество кинозрителей в 1942 г.

В 1943-1944 гг. на киноэкранах республики основным репертуаром в кинотеатрах и передвижках составляли фильмы на военную тематику: «Парень из нашего города» (1942 г. $)^{4}$, «Она защищает Родину» $(1943 \text { г. })^{5}$, «Непобедимые» $(1942 \text { г. })^{6}$, «Во имя Родины» $(1943 \text { г. })^{7}$, «Два бойца» $(1943 \text { г. })^{8}$, «Урал кует Победу» $(1943 \text { г. })^{9}$, «Фронт» $(1943 \text { г. })^{10}$.

В ТНР также повторно показывались специальные выпуски «Союзкинохроники» и другие художественные фильмы: «Ленин в октябре» $(1939 \text { г. })^{11}$, «Мечта» $(1941 \text { г. })^{12}$, «Лермонтов» $(1943 \text { г. })^{13}$, «Радуга» $(1943 \text { г. })^{14}$ и документальный фильм о Туве «Страна голубой реки» ${ }^{15}$ (1941 г.).

В целом за 1943 г. показатели по кинообслуживанию населения по всей республике был выполнен и составил 3130 киносеансов с охватом 313307 человек. Интересные наблюдения выходят из сведений, составленных управляющим Госкино Таржаа за 1943 г., где ориентировочный учет кинопосещений велся и по национальной принадлежности граждан (НА РТ, ф. 145, оп. 1, д. 1, л. 1) (фото 12).

Таким образом, в годы Великой Отечественной войны система кинофикации и киносети испытывала сложности материально-технического характера, связанных прежде всего с проблемой доставки фильмов и топлива из Советского Союза. Программа пятилетки, предусматривающая увеличение роста киносети в республике не была достигнута, за годы войны не было приобретено ни одной киноустановки. Многие из имевшихся передвижек пришли в негодность, что привело к сокращению количества до 20 единиц (в 1937 г. - было 28). Репертуарная политика военного периода стала важным средством в патриотическом воспитании общества. В целом, несмотря на сложившиеся обстоятельства того времени, работники Госкино старались выполнять свои задачи, делая кино общедоступным для простого народа.

\section{Заключение}

Подводя итоги исследования, можно отметить, что кино в Туве, претерпев трудности на начальном этапе развития в конце 1920-1930-е гг. (слабость материально-технической базы, трудность обеспечения кадрами, существенный контроль за репертуарной политикой и постоянная работа со зрителем), успело сформироваться в функционирующую систему, которая работала и выполняла свои задачи в 1940-е гг. Система кинофикации стала одним из основных методов агитации и пропаганды новой культурной революции, затем, во время войны - средством патриотического воспитания, любви к родине и ненависти к захватчикам.

Первые немые киноустановки, появившиеся в ТНР в 1926 г., за почти два десятилетия стали выполнять развлекательные, информационно-коммуникативные, идеологические, политические и интеграционные функции кинематографа. Первые работники кино, получившие новую профессию в ТНР, стали очень востребованными, уважаемыми и известными людьми во всей республике.

\footnotetext{
${ }^{1}$ Тувинская правда. 1942. № 47. 27 мая. С. 3.

${ }^{2}$ Тувинская правда. 1942. № 135. 9 декабря. С. 4.

${ }^{3}$ Тувинская правда. 1942. № 128. 9 декабря. С. 1.

${ }^{4}$ Тувинская правда. 1943. № 36. 2 апреля. С. 4.

${ }^{5}$ Тувинская правда. 1943. № 82. 4 августа. С. 3.

${ }^{6}$ Тувинская правда. 1943. № 86. 13 августа. С. 6.

${ }^{7}$ Тувинская правда. 1943. № 104. 29 сентября. С. 4.

${ }^{8}$ Тувинская правда. 1943. № 127. 3 декабря. С. 4.

${ }^{9}$ Тувинская правда. 1944. № 7. 21 января. С. 6.

${ }^{10}$ Тувинская правда. 1944. № 8.26 января. С. 4.

${ }^{11}$ Тувинская правда. 1944. № 5. 15 января. С. 4.

${ }^{12}$ Тувинская правда. 1943. № 143. 20 ноября. С. 6.

${ }^{13}$ Тувинская правда. 1943. № 132.18 декабря. С. 5.

${ }^{14}$ Тувинская правда. 1944. № 46. 3 июня. С. 4.

${ }^{15}$ Тувинская правда. 1943. № 86. 13 августа. С. 6.
} 
В первые месяцы вхождения Тувы в состав СССР, а если точнее - по данным на 1 января 1945 г. киносеть Тувы представляла собой организованную систему из 6 кинотеатров (в Кызыле - 2, по одному в Туране, Шагонаре, Чадане, Баруун-Хемчике), 2 стационарных кинопередвижки (в городском парке Кызыле), 11 передвижных установок. Всего в Госкино работало 48 рабочих и служащих. Киносеть Тувы продолжила свое развитие уже в составе СССР, влившись в единую систему советского кинопроката.

\section{СПИСОК ЛИТЕРАТУРЫ}

Анчима, Х. А. (1970) Культурное строительство в Советской Туве // В братской семье народов / сост. С. С. Сонам. Кызыл : Типография управления по печати при Совете Министров Тувинской АССР. 216 с. С. 55-69.

Аранчын, Ю. Л. (1982) Исторический путь тувинского народа к социализму. Новосибирск : Наука. 337 с.

Бадыргы, М. М., Мунге, Б. В. (2020) Документы Национального архива Республики Тыва по культурному строительству Тувинской Народной Республики // Новые исследования Тувы. № 2. C. 145-164. DOI: www.doi. org/10.25178/nit.2020.2.10

Бураева, С. В., Батурин, С. А. (2017) Бурятия в пространстве документального советского кино (1923-1941 гг.) // Вестник Восточно-Сибирского государственного института культуры. № 4. С. 62-71.

Введение (2007) // Урянхай. Тыва дептер : в 7 т. / сост. С. К. Шойгу. М. : Слово/Slovo. Т. 6. Танну-Тувинская Народная Республика (1921-1944 гг.). 584 с. С. 29-127.

Галкин, А. В. (2009) О работе киносети Чувашии в годы Великой Отечественной войны // Вестник Чувашского университета. № 3. С. 35-39.

История Горного Алтая (2014) / А. П. Адлыкова, Т. В. Анкудинова, А. Г. Гонохов и др. Горно-Алтайск : ГорноАлтайский государственный университет. 480 с.

История Тувы (2007) : в 3 т. / под общ. ред. В. А. Ламина. Новосибирск: Наука. Т. 2. 430 с.

Кино: Энциклопедический словарь (1986) / гл. ред. С. И. Юткевич; редкол.: Ю. С. Афанасьев, В. Е. Баскаков, И. В. Вайсфельд и др. М. : Советская энциклопедия. 838 с.

Киносеть (1973) // Большая советская энциклопедия : в 30 т. / под ред. А. М. Прохорова. М. : Советская энциклопедия, 1969-1978. Т. 12. 624 с. С. 138.

Косых, Е. Н., Фадеев, К. В. (2005) Сибирский кинематограф: 1896-1917 гг. // Процессы урбанизации в Центральной России и Сибири: сборник статей / под ред. В. А. Скубневского. Барнаул : Изд-во Алтайского университета. 319 c. С. 305-318.

Кужугет, А. К. (2006) Духовная культура тувинцев: структура и трансформация. Кемерово : КемГУКИ. 319 с.

Кызыл - столица Советской Тувы (1964) / Очур В. Ч., Ровнов В. И., Сердобов Н. А. и др. Кызыл : Тувинское книжное издательство. 129 с.

Маннай-оол, М. Х. (2001) Ученый комитет ТНР и его роль в социально-экономическом и культурном развитии Тувы // Гуманитарные исследования в Туве : сборник научных статей / отв. ред. К. А. Бичелдей, Б. И. Татаринцев, С. М. Биче-оол. М. : РУДН. 336 с. С. 99-106.

Менхен-Хельфен, О. (2007) Путешествие в азиатскую Туву // Урянхай. Тыва дептер / составитель С. К. Шойгу : в 7 т. М. : Слово/Slovo. Т. 6.584 с. С. 222-351.

Моллеров, Н. М. (1988) Очаги социалистической культуры РСТК в ТНР (1922-1932) // Культура тувинцев: традиция и современность / отв. ред. Ю. Л. Аранчын. Кызыл : Типография Госкомиздата Тувинской АССР. 152 с. С. 100-109.

Потапов, Л. П. (1953) Социалистическое переустройство культуры и быта тувинцев // Советская этнография. № 2. С. $72-102$. 482 c.

Сердобов, Н. А. (1971) История формирования тувинской нации. Кызыл : Тувинское книжное издательство.

Сталин, И. В. (1953) О Великой Отечественной войне Советского Союза (доклады, речи, выступление и приказы). М. : Госполитиздат. 209 с.

Тока, С. К. (1970) Торжество ленинской национальной политики КПСС // В братской семье народов / отв. ред. С. К. Тока. Кызыл : Типография управления по печати при Совете Министров Тувинской АССР. 213 с. С. 7-15.

Ховалыг, С. С. (2020) Проблемы хранения технотронных документов в архивах Тувы // Новые исследования Тувы. № 2. С. 63-74. DOI: www.doi.org/10.25178/nit.2020.2.4 
Храмкова, Н. П., Заводчиков, В. В. (2017) Кадровое обеспечение системы кинообслуживания населения среднего Поволжья в годы Великой Отечественной войны // Общество: философия, история, культура. № 4. C. 98-103. DOI: www.doi.org/10.24158/fik.2017.4.24

Энциклопедия Республики Хакасия (2007) : в 2 т. / гл. ред. В. А. Кузьмин. Красноярск : Поликор. Т. 1. 432 с.

Дата поступления: 01.06.2020 г.

\section{REFERENCES}

Anchima, Kh. A. (1970) Kul'turnoe stroitel'stvo v Sovetskoi Tuve [Cultural construction in Soviet Tuva]. In: V bratskoi sem'e narodov [In the brotherly family of peoples]. Ed. by S. K. Toka. Kyzyl, Printing office of the press Department of the Council of Ministers of the Tuvan ASSR. 213 p. Pp. 55-69. (In Russ.).

Aranchyn, Yu. L. (1982) Istoricheskii put' tuvinskogo naroda $k$ sotsializmu [The historical path of the Tuvan people to socialism]. Novosibirsk, Nauka. 337 p. (In Russ.).

Badyrgy, M. M. and Munge, B. V. (2020) Dokumenty Natsional'nogo arkhiva Respubliki Tyva po kul'turnomu stroitel'stvu Tuvinskoi Narodnoi Respubliki [“Cultural Upbuilding” in People's Republic of Tuva in documents preserved at National Archives of Republic of Tuva]. New Research of Tuva, no. 2, pp. 145-164. (In Russ.). DOI: www.doi.org/10.25178/ nit.2020.2.10

Buraeva, C. V. and Baturin, S. A. (2017) Buriatiia v prostranstve dokumental'nogo sovetskogo kino (1923-1941 gg.) [Buryatia in the space of documentary Soviet films (1923-1941)]. Vestnik Vostochno-Sibirskogo gosudarstvennogo instituta kul'tury, no. 4, pp. 62-71. (In Russ.).

Vvedenie [Introduction] (2007). In: Uriankhai. Tyva depter [Uriankhai: The Tuvan Notebook]: in 7 vols. / comp. S. K. Shoigu. Moscow, Slovo. Vol. 6. Tannu-Tuvinskaia Narodnaia Respublika (1921-1944 gg.) [Tannu-Tuva People's Republic (1921-1944).]. 584 p. Pp. 29-127. (In Russ.).

Galkin, A. V. (2009) O rabote kinoseti Chuvashii v gody Velikoi Otechestvennoi voiny [On the work of the film network of Chuvashiya within Great Patriotic War]. Vestnik Chuvashskogo universiteta, no. 3, pp. 35-39. (In Russ.).

Istoriia Gornogo Altaia [History of the Altai Mountains] (2014) / A. P. Adlykova, T. V. Ankudinova, A. G. Gonokhov et al. Gorno-Altaisk, Gorno-Altaisk state University. 480 p. (In Russ.).

Istoriia Tuvy [The History Of Tuva] (2007): in 3 vols. / ed. by V. A. Lamin. Novosibirsk, Nauka. Vol. 2. 430 p. (In Russ.).

Kino: Entsiklopedicheskii slovar' [Cinema: An Encyclopedic dictionary] (1986) / editor-in-chief S. I. Yutkevich; editorial board: Yu. S. Afanas'ev, V. E. Baskakov, I. V. Vaisfel'd et al. Moscow, Sovetskaia entsiklopediia. 838 p. (In Russ.).

Kinoset' [Cinema] (1973). In: Bol'shaia sovetskaia entsiklopediia [Great Soviet encyclopedia]: in 30 vols. / ed. by A. M. Prokhorov. Moscow, Sovetskaia entsiklopediia, 1969-1978. Vol. 12. 624 p. Pp. 138. (In Russ.).

Kosykh, E. N. and Fadeev, K. V. (2005) Sibirskii kinematograf: 1896-1917 gg. [Siberian cinema: 1896-1917]. In: Protsessy urbanizatsii $v$ Tsentral'noi Rossii i Sibiri: sbornik statei [Processes of urbanization in Central Russia and Siberia: a collection of articles] / ed. by V. A. Skubnevskii. Barnaul, Publishing house of the Altai University. 319 p. Pp. 305-318. (In Russ.).

Kuzhuget, A. K. (2006) Dukhovnaia kul'tura tuvintsev. Struktura i transformatsiia [The immaterial culture of Tuvans. Structure and transformation]. Kemerovo, KemGUKI. 319 p. (In Russ.)

Kyzyl - stolitsa Sovetskoi Tuvy [Kyzyl, the capital of Soviet Tuva] (1964) / Ochur V. Ch., Rovnov V. I., Serdobov N. A. et al. Kyzyl, Tuva book publishing house. 129 p. (In Russ.).

Mannai-ool, M. Kh. (2001) Uchenyi komitet TNR i ego rol'v sotsial'no-ekonomicheskom razvitii Tuvy [The TPR Academic Committee and its role in socioeconomic and cultural development of Tuva]. In: Gumanitarnye issledovania $v$ Tuve: sbornik nauchnykh statei [Humanities Research in Tuva: collected scholarly articles]. Ed. by K. A. Bicheldei, B. I. Tatarintsev and S. M. Biche-ool. Moscow, RUDN. 336 p. Pp. 102-104. (In Russ.).

Menkhen-Khel'fen, O. (2007) Puteshestvie v aziatskuiu Tuvu [A Journey to Asian Tuva]. In: Uriankhai. Tyva depter [Uryankhai: A Tuvan Notebook]: in 7 vols. / comp. by S. K. Shoigu. Moscow, Slovo/Slovo. Vol. 6. 584 p. Pp. 222-351. (In Russ.).

Mollerov, N. M. (1988) Ochagi sotsialisticheskoi kul'tury RSTK v TNR (1922-1932) [Centers of socialist culture of the RSTC in TPR (1922-1932)]. In: Kul'tura tuvintsev: traditsiia i sovremennost' [Culture of Tuvans: tradition and modernity] / ed. by Yu. L. Aranchyn. Kyzyl, Printing house of the state Committee of The Tuvan ASSR. 152 p. Pp. 100-109. (In Russ.).

Potapov, L. P. (1953) Sotsialisticheskoe pereustroistvo kul'tury i byta tuvintsev [The socialist reconstruction of the culture and life of Tuvan people]. Sovetskaia etnografiia, no. 2, pp. 72-102. (In Russ.).

Serdobov, N. A. (1971) Istoriia formirovaniia tuvinskoi natsii [The history of the formation of the Tuvan nation]. Kyzyl, Tuvan book publisher. 482 p. (In Russ.). 
Stalin, I. V. (1953) O Velikoi Otechestvennoi voine Sovetskogo Soiuza (doklady, rechi, vystuplenie i prikazy) [About the Great Patriotic War of the Soviet Union (reports, speeches, speeches and orders)]. Moscow, Gospolitizdat. 209 p. (In Russ.).

Toka, S. K. (1970) Torzhestvo leninskoi natsional'noi politiki KPSS [The triumph of Leninist national politics of the CPSU]. In: V bratskoi sem'e narodov [In the brotherly family of peoples]. Ed. by S. K. Toka. Kyzyl, Printing office of the press Department of the Council of Ministers of the Tuvan ASSR. 213 p. Pp. 7-17. (In Russ.).

Khovalyg, S. S. (2020) Problemy khraneniia tekhnotronnykh dokumentov v arkhivakh Tuvy [Preserving technotronic documents in the archives of Tuva]. New Research of Tuva, no. 2, pp. 63-74. (In Russ.). DOI: www.doi.org/10.25178/ nit.2020.1.4

Khramkova, N. P. and Zavodchikov, V. V. (2017) Kadrovoe obespechenie sistemy kinoobsluzhivaniia naseleniia srednego Povolzh'ia v gody Velikoi Otechestvennoi voiny [Staffing the cinema entertainment system of the population of the middle Volga region during the Great Patriotic War]. Obshchestvo: filosofiia, istoriia, kul'tura, no. 4, pp. 98-103. (In Russ.). DOI: www.doi.org/10.24158/fik.2017.4.24

Entsiklopediia Respubliki Khakasiia [Encyclopedia of the Republic of Khakassia] (2007) : in 2 vol. / editor-in-chief V. A. Kuz'min. Krasnoiarsk, Polikor. Vol. 1. 432 p. (In Russ.).

Submission date: 01.06.2020. 